\title{
Sejarah Perkembangan Kekuasaan Kehakiman di Indonesia
}

\author{
Ridham Priskap \\ Dosen Fakultas Hukum dan Magister Ilmu Hukum Universitas Jambi \\ Correspondence email: ridham_priskap@unja.ac.id
}

\begin{abstract}
Abstrak. Kekuasaan Kehakiman di Indonesia dari dulu sampai sekarang tetap eksis walaupun mengalami pasang surut, sejarah pperkembangan lembaga ini sudah dimulai jauh sebelum kemerdekaan, bahkan sebelum Hindia Belanda bercokol di bumi nusantara ini kekuasaan kehakiman telah eksis dalam bentuk lembaga peradilan adat. Sebagai lembaga yang memberi perlindungan terhadap masyarakat kekuasaan kehakiman dari masa kemasa telah menunjukkan fungsi-fungsinya sebagai benteng terakhir untuk mencari keadilan hukum bagi masyarakat.
\end{abstract}

Keywords: perkembangan; kekuasaan kehakiman

Abstract. Judicial power in Indonesia from the past until now still exists despite the ups and downs, the history of the development of this institution has begun long before independence, even before the Dutch East Indies were entrenched in the archipelago, this judicial authority has existed in the form of traditional justice institutions. As an institution that provides protection to the community, the judicial authority has shown its functions as the last stronghold to seek legal justice for the community.

Keywords: development; judicial power

\section{PENDAHULUAN}

Salah satu fungsi pokok kekuasaan kehakiman adalah untuk memutus perkara dengan menerapkan hukum materil secara paksa, pada sisi lain dapat dilihat bahwa arti penting kekuasaan kehakiman adalah untuk memutus sengketa hukum yang timbul antara anggota masyarakat satu sama lain dan antara anggota masyarakat dengan pihak pemerintah. Kewenangan untuk memutus perkara itu tujuan akhirnya sudah barang tentu untuk mewujudkan ketertiban umum di masyarakat melalui putusan yang adil. Diskusi tentang kewenangan pokok mengadili tidak bisa dilepaskan kaitannya dengan luas ruang lingkup kekuasaan kehakiman. Luas ruang lingkup kekuasaan kehakiman itu dapat didekati dari dua aspek yaitu: pertama, aspek institusional berupa jenisjenis kelembagaan Peradilan yang diserahi kekuasaan kehakiman; kedua, aspek fungsional berupa ragam fungsi yang diserahkan oleh Undang-undang kepada kekuasaan kehakiman.

Khusus untuk aspek yang pertama sebagai institusi Peradilan dipandang perlu menelusuri perkembangan kelembagaan itu mulai dari jaman kolonial hingga jaman kemerdekaan. Penelusuran ini di samping bertujuan untuk memperluas wacana bahasan, juga didasari pada pemahaman bahwa konsep keadilan dan ketertiban umum seperti diingkatkan oleh Friedman (1983:37), bahwa konsep kekuasaan kehakiman bukanlah konsep yang statis melainkan konsep yang terus berkembang (... "it should, however be borne in mind that public order itself is not a static concept").

Dilihat dari sejarahnya kekuasaan kehakiman telah mengalami perkembangan yang sangat panjang sesuai situasi dan kondisi politik yang terus berkembangan menurut era ketatanegaraan yang mengikutinya. Untuk melihat sejarah pekembangan kekuasaan kehakiman tersebut paling tidak penelusuran harus dikaji pada tiga tahapan, yaitu tahap pemerintahan Hindia Belanda dimana badan-badan peradilan sebagai pelaksana kekuasaan kehakiman bersifat pluralistik dan diskriminatif karena adanya perbedaan peradilan yang khusus untuk orang-orang eropa atau yang dipersamakan dengannya dan ada badan peradilan yang khusus untuk golongan pribumi seperti adanya peradilan Gubernemen dan peradilan Adat.

Peradilan Gubernemen mengadili atau melaksanakan fungsinya atas nama Raja atau Ratu Belanda, sedangkan Peradilan Adat tidak demikian halnya. Kebijakan yang diambil pemerintah Hindia Belanda mengenai peradilan adalah dengan mengeluarkan Staatblad 1932 Nomor 80 yang mengatur tentang susunan dan kedudukan, kekuasaan mengadili, hukum materil dan hukum acara badan Peradilan Adat. Disamping itu diberi kewenangan kepada Residen untuk menyusun peraturan pelaksanaannya. Dalam prakteknya peradilan ini bukanlah bentuk peradilan yang bebas dan merdeka karena Residen mempunyai kewenangan untuk membatalkan putusan pengadilan adat atau memerintahkan pemeriksaan kembali oleh hakim yang ditunjuk oleh Residen dan Residen berkuasa untuk menetapkan bahwa seseorang tidak termasuk ke dalam jurusdiksi Peradilan Adat setempat.

Pada masa pemerintahan Jepang dimana tujuannya hanya untuk melindungi kepentingan dan keselematan prajurit yang sedang mengalami peperangan sehingga karakteristik pemerintah penjajahan Jepang di Indonesia adalah pemerintah militer dengan tujuan utamanya adalah untuk menjaga keselamatan dan keamanan personil militer Jepang demi tercapainya 
tujuan perang. Sesuai dengan karakteristik dan tujuan perang maka yang pertama-tama dibentuk oleh pemerintah militer Jepang adalah peradilan yang melindungi militer yang disebut Gunritukaigi.

Dalam sejarah ketatanegaraan Indonesia setelah kemerdekaan, kekuasaan kehakiman mendapat penataan secara sungguh-sungguh walaupun dalam berbagai hal model kekuasaan kehakiman yang dirumuskan masih menggambarkan adanya kekurangan dan kelemahan yang belum sepenuhnya dapat difungsikan sebagai lembaga yang memberi keadilan dan pengayoman masyarakat. Bertolak dari pemikiran yang demikian dianggap perlu untuk mencermati dan mengakaji sejarah perkembangan kekuasaan kehakiman di Indonesia yang pengkajiannya dilakukan baik pada masa sebelum kemerdekaan dan sesudah kemerdekaan Negara Republik Indonesia.

\section{Rumusan Masalah}

Dari apa yang diuraikan di atas, permalasahan yang akan dibahas dalam tulisan yang singkat ini dibatasi pada:

1. Kekuasaan Kehakiman pada Masa Pemerintahan Hindia Belanda

2. Kekuasaan Kehakiman Masa Pemerintahan Militer Jepang

3. Kekuasaan Kehakiman Setelah Kemerdekaan Republik Indonesia

\section{HASIL DAN PEMBAHASAN \\ Kekuasaan Kehakiman pada Masa Pemerintahan Hindia Belanda}

Pada masa pemerintahan kolonial Hindia Belanda, kekuasaan kehakiman dilaksanakan oleh empat badan Peradilan yang dalam bahasa Belanda dikenal dengan istilah rechtspraaken, peradilan yang dimaksud terdiri dari: (Sotoprawiro, 1994:91-92):

1) Peradilan Gubernemen (Gouvernements rechtpraak) yang meliputi seluruh Hindia Belanda.

2) Peradilan Pribumi (Inheemscherecht-spraak) hanya terdapat di daerah langsung (administratif) daerah seberang.

3) Peradilan Swapraja (Zelfbestuurs rechtspraak) yang terdapat di daerah tidak langsung (otonom), kecuali daerah Swapraja Paku Alaman dan Pontianak.

4) Peradilan Desa (Dorps rechtspraak), dengan catatan, di samping yang berdiri sendiri ada yang merupakan bagian dari Peradilan Gubernemen, Peradilan Swapraja, maupun Peradilan Adat.

Pada masing-masing jenis Peradilan itu, dimungkinkan pula adanya sejenis kamar berupa Kamar Peradilan Agama (Godsdienstige Rechtspraak). Untuk lebih jelasnya pada bagian di bawah ini akan diuraikan beberapa peradilan yang ada pada jaman pemerintahan Hindia Belanda. Badan-badan peradilan tersebut terdiri dari:

\section{Peradilan Gubernemen}

Peradilan Gubernemen terdiri dari dua bagian yaitu Peradilan Sipil dan Peradilan Militer. Peradilan Sipil terdiri atas 4 (empat) kamar yaitu:

1) Lansdgerecht dimana peradilan ini berlaku untuk semua golongan.

2) Inlandsche Rechtspraak atau Peradilan Pribumi, yang pada prinsipnya berlaku untuk golongan Pribumi. Untuk daerah Jawa dan Madura Peradilan bawahan berupa Districtsgerecht dan Regentschaosgerecht. Peradilan atasan dari kedua jenis Peradilan itu adalah Peradilan Landraad. Untuk daerah Seberang Peradilan bawahan berupa: Negorijrechtbank, Districsgerecht/Districtsraad, dan Magistraats-gerecht. Sama dengan di daerah Jawa dan Madura Peradilan atasan dari kesemua peradilan itu adalah Peradilan landraad.

3) Europeesche Rechtspraak (Peradilan Eropa), pada prinsipnya berlaku untuk golongan Eropa, susunan peradilan ini pada tingkat banding dikenal dengan Raad van Justitutie dan tingkat kasasi berupa Hoog Gerechtshof van Nederlandsche Indie.

4) Peradilan Agama, peradilan ini mengadili perkara agama Islam. Peradilan jenis ini terdapat: di Jawa dan Madura berupa: Priesterraad dan Hof voor Islamictische Zaken; Di Banjarmasin dan Hoeloe Soengai berupa Qadi; sedangkan di daerah lain seperti Palembang, Jambi, Pontianak, Ternate, Ambon, Makasar dan lain-lain, disesuaikan dengan sebutan yang dikenal di daerahnya masing-masing, dan pada umumnya menggunakan sebutan Qadi.

Sementara peradilan yang merupakan bagian dar Peradilan Militer terdiri dari Krijgsraad. Zeekrijgsraad, dan Hoog Militer Gerechtshof. Krijgsraad merupakan peradilan militer yang terdapat di Cimahi, Makasar dan Padang. Pengadilan Krijgsraad ini mempunyai kekuasaan dan berwenang mengadili perkara tentara Belanda (KNIL) yang berpangkat Kapten ke bawah, sedang Zeekrijgsraad merupakan pengadilan Militer yang pada prinsipnya sama dengan Krijgsraad, perbedaannya hanyalah bahwa Peradilan ini diselenggarakan di atas kapal perang. Sebagai Peradilan militer tertinggi adalah apa yang dikenal dengan sebutan Hoog Militair Gerehtshof yaitu peradilan yang berkedudukan di Batavia. Kewenangan dari Hoog Militair Gerehtshof adalah memeriksa perkara pada tingkat banding dari Krijgsraad dan Zeekrijgsraad, serta merupakan Peradilan pertama dan tertinggi dari kalangan tentara yang berpangkat perwira ke atas.

\section{Peradilan Adat}

Dasar hukum Peradilan Adat sama dengan dasar hukum Peradilan Gubernemen yaitu Pasal 130 Indische Staatregering (IS) atau Undang-undang Dasar Hindia Belanda.Walaupun kedua peradilan ini dibentuk dengan dasar hukum yang sama, namun terdapat perbedaan yang sangat prinsipil. Peradilan Gubernmen mengadili atau 
melaksanakan fungsinya atas nama Raja/Ratu Belanda, sedangkan Peradilan Adat tidak. Meskipun demikian, pemerintah Hindia Belanda mempunyai pengaruh yang cukup besar dari segi pengaturan dan pengangkatan hakim-hakim badan Peradilan Adat ini. Pada awalnya Peradilan Adat ini hanya terdapat di daerah daerah seberang yang pelaksanaannya dilakukan menurut hukum adat masing-masing, kemudian terjadi perkembangan karena adanya perubahan sikap pemerintah Belanda untuk membina Peradilan Adat itu. Kebijakan yang diambil pemerintah Hindia Belanda adalah mengeluarkan Staatblad 1932 Nomor 80 yang mengatur tentang susunan dan kedudukan, kekuasaan mengadili, hukum materil dan hukum acara badan Peradilan Adat. Disamping itu diberi kewenangan kepada Residen untuk menyusun peraturan pelaksanaannya.

Dilihat dari sudut pandang kedudukan dan tingkatannya, pada umumnya badan Peradilan Adat ini terdiri dari tiga tingkatan pengadilan yang dikenal dengan:

1) Pengadilan Tingkat Desa (Rapat)

2) Pengadilan Tingkat Rendah (Kleine Rapat)

3) Pengadilan Tingkat Tinggi (Groote Rapat).

Pengadilan desa (Rapat) dengan pengadilan

Tingkat Rendah (Kleine Rapat) pada prinsipnya memiliki kedudukan (tingkatan) yang relatif sama. Pengadilan Desa hanya dapat mengadili urusan-urusan kecil yang dilakukan oleh anggota persekutuan adat setempat. Sedangkan Kleine Rapat mengadili unsurunsur kecil yang dilakukan oleh orang pribumi bukan penduduk setempat. Di sisi lain, Groote Rapat merupakan pengadilan Tingkat Banding bagi kedua jenis pengadilan tersebut, atau menjadi pengadilan pertama bila di daerah tersebut tidak terdapat pengadilan Desa dan atau pengadilan Tingkat Rendah. Di beberapa daerah seperti di Lombok terdapat pula pengadilan agama yang mempunyai tingkatan yang sejajar dengan pengadilan Desa dan Kleine Rapat. Dalam prakteknya peradilan ini bukanlah bentuk peradilan yang bebas dan merdeka karena Residen mempunyai kewenangan untuk membatalkan putusan pengadilan adat atau memerintahkan pemeriksaan kembali oleh hakim yang ditunjuk oleh Residen.

Berdasarkan pada Staatblad Tahun 1932 Nomor 80, Jurisdiksi Peradilan Adat diatur sebagai berikut:

1) Pengadilan Adat berwenang mengadili perkara yang terjadi di wilayah kekuasaan Badan Peradilan Adat.

2) Semua orang pribumi dari mana pun asalnya dapat menjadi terdakwa atau pun tergugat.

3) Semua golongan penduduk dapat menjadi penggugat.

Dalam kaitannya dengan Peradilan Adat ternyata

kekuasaan Residen cukup besar. Residen berkuasa untuk menetapkan bahwa seseorang tidak termasuk ke dalam jurusdiksi Peradilan Adat setempat. Peradilan Adat tidak berwenang mengadili perkara kejahatan yang menyangkut aspek keamanan dan ketertiban. Terhukum dalam Peradilan Adat dapat meminta grasi, amnesti dan abolisi kepada Gubernur Jenderal Hindia Belanda. Peradilan Adat terdapat di wilayah:

1) Onderafdeeling Padanglawas, Afdeelingen Bataklanden dan Nias kecuali Batoe-Eilanden (Residentie Tapanoeli);

2) Onderafdeeling Mentawai-Eilanden dan Distrik Kerinci (Residentie Sumatra's Weskust);

3) Residentie Bengkoelen, kecuali ibukotanya;

4) Residentie Palembang, kecuali ibukotanya;

5) Bekas kesultanan Riau-Lingga (Residentie Riow en Onderhoorigheden);

6) Onderafdeelingen Boven-Mahakam dan Pasir (Residentie Zuider en Ooster Afdeeling van Borneo);

7) Bekas kerajaan Gorontalo (Resindetie Manado);

8) Adatgemeenschapeen Gatarang-Matinggi, Kidnang, Laikang, Wanora Waro (Residentie Celebes en Onderhoorighheden);

9) Taoen, Nila en Seroea-eilanden; Laboeha. Obi, Kekik en Lewin eilanden (Residentie Molukken);

10) Afdeeling Groot-Aceh dan Onderafdeeling Singkel (Residentie Atjeh en Onderhoorigheden);

11) Onderafdeeling Boven-Kapoeas dan Semitaoe dan Distrik Pinohlanden dan Meliaoe (Residentie Westerafdeeling van Borneo);

12) Afdeeling Lombok (Residentie Bali en Lombok)

\section{Peradilan Swapraja}

Peradilan Swapraja diselenggarakan atas nama kepala Swapraja. Peradilan ini terdapat di setiap Kadipaten Pakoe Alaman dan Swapraja Pontianak. Keberadaan Peradilan Swapraja diakui oleh Pemerintah Hindia Belanda melalui zelfbestuurs Regelen 1938 atau Lange Contact masing-masing Swapraja. Peradilan ini ada, baik di Jawa dan Madura maupun di Daerah Seberang. Peraturan pelaksanaan mengenai susunan dan kedudukan, kekuasaan mengadili, hukum materiil dan hukum formil Badan Peradilan Swapraja ditetapkan oleh Residen setempat setelah berkonsultasi dengan Swapraja yang bersangkutan dan setelah mendapat persetujuan dari Departemen Van Justitie. Peraturan Residen ini dibuat dengan berpedoman pada Staatblad 1932 Nomor 80, tentang Badan Peradilan Adat. Oleh karena itu, tidak ada perbedaan yang mendasar antar Peradilan Swapraja di Daerah Seberang dengan Peradilan Adat. Perbedaannya, hanya terbatas pada kewenangan penguasa Europessch Bestur untuk bertindak sebagai penasehat, dan bukan sebagai Ketua Groote Rapat.

Dapat ditambahkan bahwa Peradilan Swapraja di Kesultanan Deli dan Swapraja Baroesdjahe, Lingga, Soeka, Sarinembah dan Koetaboeloeh yang termasuk dalam wilayah Onderafdeeling Karolanden, Residentie Oostkust van Sumatera mempunyai Pengadilan Desa sebagai pengadilan bawahannya. Sementara Peradilan Swapraja di Kesultanan Deli dan Swapraja Poerba Dolok dan Si Lima Hoeta yang juga termasuk wilayah 
Onderafdeeling Karolanden, Residentie OosEust Van Sumatera memiliki pula Kamer Agama sebagai salah satu unsurnya.

Menurut Soetoprawiro (1994:118-122) badanbadan Peradilan Swapraja yang dibentuk di Jawa dan Madura terdapat di Kesultanan Ngyogyakarta Hadiningrat yang dibentuk berdasarkan pada ketentuan Rijksblad 1927 Nomor 35, di Kesunanan Soerakarta Hadiningrat dibentuk berdasarkan Rijksblad 1930 Nomor 6 dan Kadipaten Mangkunegara berdasarkan Rijksblad 1917 Nomor 22. Peradilan Swapradja di Kasultanan Ngayogyakarta meliputi:

a) Peradilan Surambi

Pengadilan Surambi pada hakekatnya merupakan sebuah peradilan agama, diketuai oleh seorang Penghulu Hakim (Hoofdpenghoeloe) sebagai hakim tunggal. Pengadilan ini berwenang mengadili perkara nikah, talak dan waris bagi kerabat Sultan serta rapak (permohonan cerai oleh istri) bagi semua kaula. Banding atas putusan ini dapat dimintakan pada Patih dan selanjutnya pada Sultan karena dalam peradilan surambi kedudukan Sultan sebagai pemegang kekuasaan peradilan tertinggi.

b) Pengadilan Keraton Daerah Dalem

Pengadilan ini adalah pengadilan majelis yang terdiri dari seorang Ketua dan dua orang anggota, dibantu oleh seorang Panitera ditambah seorang jaksa dan seorang Penghulu. Semua pejabat itu diangkat oleh Sultan. Ketua pengadilan biasanya dijabat oleh Pangeran Pati (Putera Mahkota) atau Pangeran Ngabehi (Putra sulung dari istri selir) atau Pangeran yang ditunjuk oleh Sultan. Pengadilan ini berwenang mengadili perkara pidana yang sejenis dengan perkara yang ditangani oleh Landsgerecht. Sedangkan untuk perkara perdata pengadilan ini dapat mengadili semua perkara yang tidak ditangani oleh Surambi atau Sultan sendiri. Banding atas putusan dapat dimintakan pada Sultan.

c) Pengadilan oleh Sultan

Sultan mengadili sendiri pada tingkat pertama dan terakhir semua tindak pidana yang dilakukan oleh Pangeran Pati dan keluarganya, semua para istri sultan sendiri dan para istri sultan yang terdahulu dengan keluarganya. Untuk perkara perdata Sultan berwenang mengadili semua perkara yang tidak berada dalam kewenangan pengadilan Surambi.

Sedangkan kekuasaan dan wewenang yang dimiliki oleh Peradilan Swapraja di Kasunanan Soerakarta Hadiningrat meliputi:

a) Peradilan Pradata

Pengadila ini dilakukan oleh seorang hakim tunggal dan seorang Panitera. Kewenangan peradilan perdata sama dengan kewenangan Peradilan Landsgerecht.

b) Peradilan Surambi

Peradilan ini pada hakikatnya merupakan sebuah peradilan agama yang dilaksanakan oleh seorang Wedana Yogaswara (pejabat agama Kasunanan
Soerakarta) sebagai hakim tunggal. Kawenangan peradilan Surambi adalah mengadili perkara nikah, talak, rujuk, dan waris. Permintaan banding atas putusan surambi dapat dimintakan pada Peradilan Pradata Gede.

c) Peradilan Perdata Gede

Peradilan ini merupakan perdilan tertinggi dengan sistem majelis, dimana Majelis hakim terdiri dari seorang Ketua dan dua orang hakim anggota. Pejabat lainnya adalah seorang jaksa dan seorang penghulu. Semua pejabat ini diangkat oleh Patih. Kewenangan peradilan ini adalah mengadili perkara pidana dan perdata.

Sama hal dengan apa yang terdapat di Kasultanan Ngayogyakarta Hadingingrat dan Kasunanan Soerakarta Hadiningrat peradilan Swapraja di Kadipaten Mangkoenegaran meliputi:

a) Peradilan Surambi

Peradilan Surambi di Kadipaten Mangkoenegaraan adalah merupakan peradilan agama dengan sistem majelis. Bertindak sebagai hakim ketua adalah Penghulu Hakim dengan dibantu oleh beberapa Khatib sebagai hakim anggota. Kewenangan peradilan ini adalah mengadili perkara nikah, talak, rujuk dan waris. Permintaan banding atas putusan peradilan ini dapat dimintakan pada Peradilan Pradata.

b) Peradilan Pradata

Peradilan ini merupakan pengadilan majelis yang diketui oleh Patih dengan dibantu sejumlah anggota Panitera, ditambah jaksa dan seorang penghulu. Akan tetapi berkenan dengan perkara pidana sumir, pengadilan ini mengadili dengan sistem hakim tunggal. Kewenangan peradilan Pradata adalah mengadili semua perkara pidana dan perdata yang bukan merupakan kewenangan Peradilan Surambi.

\section{Peradilan Desa}

Dalam prakteknya dikenal ada dua jenis Peradilan Desa, yaitu pertama Peradilan Desa yang merupakan bagian dari Badan Peradilan Gubernemen, dan kedua Peradilan Desa yang berdiri sendiri. Peradilan yang disebut belakangan ini, keberadaannya diakui oleh pemerintah Hindia Belanda melalui penambahan Pasal 3a ke dalam Rechtelijke Organisatie (RO). Peradilan Desa mengadili menurut hukum adat setempat dan tidak berwenang menjatuhkan putusan yang berisi hukuman. Putusan paling jauh berupa permintaan maaf, perdamaian, pengembalian keseimbangan, dan lain-lain. Para pihak bila tidak mencapai kepuasan dapat membawa perkaranya ke Peradilan Gubernemen. Hakim Peradilan Gubernemen tidak terikat pada putusan Peradilan Desa. Namun ia harus memperhatikan putusan itu dengan sungguh-sungguh.

Peradilan desa terdapat di Gubernemen Jogyakarta, Onderafdeeling Mandailing en Natal (Residentie Tapanuli) dan Minangkabau (Residentie 
Soematera's Westkust), Residentie Lampungsche Districten, Bangka en Biliton, Afdeelingen Banjarmasin dan Hoeloe Sungai (Residentie Zuider en Oosterafdeeling van Borneo), Onderafdeeling Minahasa, Residentie Manado serta sejumlah desa di Afdeeling Ambina (Residentie Molukken).

Pada umumnya Peradilan Desa itu berupa Rapat Desa yang diketuai oleh Kepala Desa yang bersangkutan. Hanya ada kekecualian di Mandailing dan Minangkabau. Di Mandailing pengadilan diselenggarakan oleh Kepala Adat sebagai hakim tunggal, sementara di Minangkabau Peradilan Desa juga mengadili perkara agama yang tersusun atas tiga tingkatan yaitu: Rapat Nagari (tingkat desa), Rapat Ninik Mamak (tingkat keluarga besar) dan terendah Rapat Kaum (tingkat keluarga kecil).

\section{Kekuasaan Kehakiman Pada Masa Penjajahan Jepang}

Karakteristik pemerintah penjajahan Jepang di Indonesia adalah pemerintah militer. Pada masa pemerintahan militer Jepang tidak ada lembaga perwakilan rakyat (badan legislatif) yang berwenang membuat Undang-undang seperti halnya suatu pemerintah demokratis yang berjalan normal. Tujuan utama pada awal pemerintahan militer Jepang di Indonesia adalah untuk menjaga keselamatan dan keamanan personil militer Jepang demi tercapainya tujuan perang seperti diungkapkan oleh Oppenheim yang kemudian disitir oleh Francois (1950:333) sebagai berikut: ... "temporarily necessitated by his interest in the maintenance and safety of his army in the realisation of the purpose of war".

Sesuai dengan karakteristik dan tujuan perang itu maka yang pertama-tama dibentuk oleh pemerintah militer Jepang adalah peradilan yang melindungi militer yang disebut Gunritukaigi. Pembentukannya didasarkan pada Osamu Gunrei Nomor 2/1942, sementara sebelumnya dengan Osamugunrei Nomor 1/1942 telah diatur tentang jenis-jenis hukuman pidana yang dapat dijatuhkan. Seiring dengan itu Gunritukaigi berwenang mengadili tindak pidana yang pada pokoknya dikualifisir sebagai kejahatan yang bersifat menggangu, menghalang-halangi dan melawan Bala tentara Jepang. Jenis hukuman dapat berupa: pidana penjara, pidana pembuangan, pidana denda dan pidana mati. Osamu Gunrei Nomor 1/1942 membenarkan penjatuhan pidana kumulatif yaitu penjatuhan bersama-sama atau penggabungan antara pidana penjara ditambah pembuangan. Juga dapat dikenakan hukuman tambahan berupa perampasan. Dengan UU tanggal 2 Maret 1942 (UU Nomor Istimewa) pidana mati dapat juga dijatuhkan terhadap perbuatan pidana yang berupa perusakan atau perampasan barang atau alat maupun sarana yang dipergunakan oleh atau berhubungan dengan tentara Jepang seperti parit-parit, perkebunan, sumber minyak, jalan, telepon, pos dan lain-lain (Mertokoesoemo, 1971:11-13).

Selain peradilan yang bersifat melindungi kepentingan milter, dengan UU Nomor 14 Tahun 1942 kemudian diubah dengan UU Nomor 34 tahun 1942 dibentuklah Gunsei Hoin yaitu Pengadilan Pemerintah Balatentara dan Gunsei Kensatu Kyoku atau Kejaksanaan Pemerintah Balatentara. Kedua Undangundang itu merupakan peraturan dasar bagi pembentukan organisasi peradilan di Jawa dan Madura. Sesuai dengan ketentuan Pasal 3 UU Nomor 1 tahun 1942, pada prinsipnya organisasi dan struktur badan peradilan sama dengan organisasi dan struktur badan peradilan sebelumnya yang berlaku pada masa Hindia Belanda dengan di sana sini diadakan perubahan seperlunya. Perubahan yang mendasar adalah:

1) Dihapuskannya perbedaan antara peradilan Gubernemen dan Peradilan Bumi Putera;

2) Hakim untuk golongan Eropa dihapuskan;

3) Hakim untuk golongan Bumi Putera kekuasaannya diperluas sehingga meliputi semua golongan;

4) Penghapusan kewenangan mengadili pada tingkat pertama dari Raad van Justitie dan Hooggerechtshof;

5) Penghapusan peradilan Residentiegerecht;

6) Perubahan istilah-istilah badan peradilan seperti "Landraad" menjadi Tihoo Hooin (Pengadilan Negeri), "Landgrecht" menjadi Keizei Hooin (Hakim Kepolisian), "Regent Schapsgercht" menjadi Gun Hooin (Pengadilan Kawedanan), "Hof voor Islamietsche Zaken" menjadi Kaikyoo Kootoo Hooin (Mahkamah Islam tinggi), "Priesterraad" menjadi Sooryoo Hooin (Rapat Agama).

Untuk daerah di luar Jawa dan Madura kondisi seperti itu baru diberlakukan pelaksanaannya berupa Timo Seirei Otsu Nomor 40 Tahun 1943 yang mulai berlaku sejak tanggal 1 Januari 1944 (Mertokoesoemo, 171:14-20).

\section{Kekuasaan Kehakiman Setelah Kemerdekaan Republik Indonesia}

Kemerdekaan Indonesia yang diproklamirkan pada tanggal 17 Agustus 1945 merupakan landasan bagi terbentuknya sistem tata hukum baru yaitu sistem hukum Ketatanegaraan Indonesia. Dengan sistem hukum baru tersebut bangsa Indonesia bertekad untuk mengganti seluruh sistem hukum kolonial dengan sistem hukum nasional Indonesia. Hal ini merupakan konsekuensi suatu negara merdeka yang dengan bebas berhak mengatur sendiri tata negara dan tata hukumnya (Joeniarto, 1968:49).

Seiring dengan tekad itu bangsa Indonesia melalui PPKI (Panitia Persiapan Kemerdekaan Indonesia) pada tanggal 18 Agustus 1945 mensyahkan berlakunya suatu UUD yang rancangannya berasal dari hasil karya BPUPKI yang berupa rancangan "Mukadimah" dan rancangan "Batang Tubuh UUD". Kedua rancangan itu diterima oleh PPKI setelah mengadakan pembahasan 
seperlunya (Machfud, 1998:32). Kemudian UUD yang disyahkan tanggal 18 Agustus 1945 itu populer dengan sebutan UUD 1945.

Sejak berlakunya UUD 1945 (tanggal 18 Agustus 1945) hingga kini telah berhasil dibuat tiga buah Undang-undang pokok yang mengatur kekuasaan kehakiman, yaitu: UU Nomor 19 Tahun 1948, UU Nomor 19 Tahun 1964 dan UU Nomor 14 Tahun 1970 sebagaimana dirobah dengan UU No.35 Tahun 1999. Ketiga UU itu diciptakan dalam rangka untuk memenuhi perintah Pasal 24 dan 25 UUD 1945. Sebelum berlakunya UU Nomor 19 Tahun 1948 sepanjang menyangkut peraturan-peraturan dan badan-badan atau institusi yang berkaitan dengan kekuasaan kehakiman berlaku peraturan-peraturan dan badan-badan sebelum kemerdekaan (masa Jepang dan Belanda). Keberlakuan semacam itu didasarkan pada ketentuan Pasal II Aturan Peralihan UUD 1945 yang pada intinya mengatakan bahwa segala badan negara dan peraturan yang ada masih terus berlaku selama belum diadakan yang baru menurut Undang-undang Dasar.

\section{Undang-undang No. 19 Tahun 1948}

Setelah Indonesia merdeka, kebijakan yang ditempuh berkaitan dengan pengembangan kekuasaan kehakiman adalah didasari pada prinsip "unifikasi", sebagai lawan dari prinsip "pluralistis" yang diterapkan pada masa pemerintah kolonial Belanda". Prinsip "unifikasi" itu kemudian muncul dalam Pasal 6 dan Pasal 7 UU No. 19 Tahun 1948. Pasal 6 menyatakan bahwa dalam negara Republik Indonesia hanya ada tiga lingkungan peradilan yaitu:

1. Peradilan Umum

2. Peradilan Tata Usaha Pemerintahan

3. Peradilan Ketentaraan

Sementara Pasal 7 UU itu menegaskan bahwa kekuasaan kehakiman dalam Peradilan Umum dilaksanakan oleh:

1. Pengadilan Negeri

2. Pengadilan Tinggi

3. Mahkamah Agung

Berdasarkan Ketentuan Pasal 6 dan Pasal 7 itu ternyata keberadaan Peradilan Agama tidak tercakup di dalamnya. Juga tidak ada ketentuan yang tegas dalam UU itu yang menghapuskan keberadaan Peradilan Agama itu. Dalam ketidakjelasan itu, ketentuan yang dapat dipakai sebagai pegangan adalah Pasal 35 ayat (2) yang menyatakan bahwa perkara-perkara perdata antara orang Islam yang menurut hukum yang hidup, harus diperiksa dan diputus menurut hukum agamanya, harus diperiksa dan diputus oleh Pengadilan Negeri yang terdiri dari seorang Hakim yang beraga Islam sebagai Ketua, dan dua orang Hakim ahli agama Islam sebagai anggota yang diangkat oleh Presiden atas usul Menteri Agama dengan persetujuan Meteri Kehakiman.

Ketidakjelasan juga terlihat pada eksistensi Peradilan Adat yang selama ini diakui keberadaannya.
Ketentuan yang berkaitan dengan hal itu diatur dalam Pasal 10 yang menyatakan bahwa perkara-perkara yang menurut hukum yang hidup dalam masyarakat desa dan sebagainya harus diperiksa dan diputus oleh pemegang kekuasaan yang tinggal tetap dalam masyarakat itu (saleh, 1977:27). Tentang Peradilan Tata Usaha Pemerintahan Pasal 66 menyatakan bahwa sepanjang dalam suatu Undang-undang tidak disebut dengan tegas perkara tata usaha pemerintahan harus diadili oleh peradilan tertentu maka Pengadilan Tinggi berwenang memeriksa dalam tingkatan pertama dan Mahkamah Agung berwenang memeriksa dalam tingkatan kedua. Sementara tentang Peradilan Ketentaraan Pasal 68 menyatakan bahwa Peradilan Ketentaraan akan diatur dengan undang-undang.

\section{Undang-undang No. 19 Tahun 1964}

Penjelasan umum UU No. 19 tahun 1964 menyatakan bahwa pembentukan UU itu didasarkan pada Ketetapan MPRS No. II/MPRS/1960 tentang Haluan Negara yang berupa Manipol Usdek. Salah satu ciri jiwa Manipol Usdek adalah menempatkan Presiden sebagai Pimpinan Nasional dan sebagai Pemimpin Besar Revolusi yang memiliki kedudukan superior terhadap lembaga-lembaga negara lainnya, termasuk terhadap kekuasaan kehakiman. Sebagai suatu UU yang berjiwa Manipol Usdek, Pasal 3 dari UU itu dengan tegas menyebutkan bahwa Pengadilan adalah alat revolusi. Senada dengan itu Pasal 14 dan Pasal 20 menekankan bahwa hukum dan hakim juga merupakan alat revolusi. Oleh karena pengadilan, hukum dan hakim merupakan alat revolusi, maka Presiden adalah sebagai pemimpin besar bangsa dan negara, demikian isi Pasal 19 UU itu.

Berkenaan dengan jenis-jenis kekuasaan kehakiman, UU tersebut mengaturnya dalam Pasal 7 yang secara garis besar berisi empat hal yaitu:

1) Kekuasaan kehakiman dilaksanakan oleh empat jenis peradilan yaitu: (1) Peradilan Umum; (2) Peradilan Agama; (3) Peradilan Militer; (4) Peradilan Tata Usaha Negara.

2) Semua pengadilan berpuncak pada Mahkamah Agung yang merupakan pengadilan tertinggi untuk semua lingkungan peradilan.

3) Keempat jenis peradilan itu secara teknis berada di bawah pimpinan Mahkamah Agung sedang secara organisatoris, administratif dan finansial berada di bawah Departemen terkait.

4) Dengan adanya keempat jenis peradilan tidak tertutup kemungkinan penyelesaian perkara perdata secara damai dapat dilakukan di luar peradilan.

Perihal poin ke-3 yang menempatkan para hakim di bawah pengawasan eksekutif melalui Departemen terkait selain di bawah pengawasan Mahkamah Agung sesungguhnya pada saat perancangan UU No. 19 Tahun 1964 itu masalah itu telah mendapat reaksi keras dari organisasi profesi para hakim. Namun reaksi keras itu ternyata kandas karena Menteri Kehakiman dalam 
pembahasan rancangan UU tetap menolak usulan organisasi profesi hakim itu (Lev, 1990:49).

Kembali kepada persoalan jenis-jenis kekuasan kehakiman, penjelasan Pasal 7 UU tersebut menyatakan bahwa:

a) Undang-undang Nomor 19 Tahun 1964 membedakan antara Peradilan Umum, Peradilan Khusus, dan Peradilan Tata Usaha Negara.

b) Peradilan Umum meliputi: pengadilan ekonomi, pengadilan subversi, dan pengadilan korupsi.

c) Peradilan Khusus terdiri dari pengadilan agama dan pengadilan militer.

Hal yang menarik dari penjelasan Pasal 7 itu, bahwa penjelasan itu tidak menyebut dengan tegas jenis Pengadilan Tata Usaha Negara apakah pengadilan ini termasuk Pengadilan Umum atau termasuk Pengadilan Khusus. Dengan kata lain, menurut UU Nomor 19 Tahun 1964 Pengadilan Tata Usaha Negara tidak dimasukkan ke dalam jenis Peradilan Khusus, melainkan dinyatakan memiliki jenis tersendiri. Dalam penjelasan Pasal 7 UU tersebut dinyatakan bahwa yang dimaksud dengan Pengadilan Tata Usaha Negara adalah apa yang disebut "Peradilan Administratif" dalam Tap MPRS No. II/MPRS/1960 yang antara lain meliputi "Peradilan Kepegawaian"

\section{Undang-undang No. 14 Tahun 1970}

Pada awal kemunculannya, pemerintah orde baru bertekad melaksanakan Pancasila dan UUD 1945 secara murni dan konsekuen. Untuk itu pemerintah segera melakukan "Legislative Review" (penilaian materi perundang-undangan oleh lembaga legislatif) dengan menciptakan empat buah Undang-undang yang sangat erat hubungannya dengan kekuasaan kehakiman, keempat Undang-undang tersebut adalah:

a) Undang-undang Nomor 25 Tahun 1968 tentang pernyataan tidak berlakunya berbagai Penetapan Presiden dan Peraturan Presiden.

b) Undang-undang Nomor 5 Tahun 1969 tentang pernyataan berbagai Penetapan Presiden dan Peraturan Presiden sebagai Undang-undang.

c) Undang-undang Nomor 6 Tahun 1969 tentang Pernyataan tidak berlakunya Undang-undang dan Peraturan Pemerintah Pengganti Undang-undang.

d) Undang-undang Nomor 7 tahun 1969 tentang Penetapan berbagai Peraturan Pemerintah Pengganti Undang-undang menjadi Undang-undang.

Undang-undang Nomor 6 Tahun 1969 yang mulai berlaku pada tanggal 5 Juli 1969 menyatakan Undangundang Nomor 19 tahun 1964 adalah salah satu Undangundang yang tidak memiliki kekuatan berlaku karena materinya bertentangan dengan UUD 1945. Namun ketidakberlakuan itu berlangsung bila telah ada Undangundang baru yang menggantikannya. Untuk keperluan penggantian itu badan legislatif kemudian berhasil menciptakan Undang-undang baru yaitu UU Nomor 14 Tahun 1970 tentang Ketentuan-ketentuan Pokok
Kekuasaan Kehakiman. Pada saat Undang-undang ini masih berupa rancangan, ada beberapa persoalan yang cukup menonjol sehingga mendapat pembahasan cukup hangat dari kalangan DPR. Persoalan-persoalan itu antara lain (Saleh, 1977:32-33):

a) Mahkamah Agung sebagai pucuk tertinggi lembaga kekuasaan kehakiman

b) Majelis Pertimbangan Penelitian Hakim (MPPH)

c) Lingkungan Peradilan

d) Organisasi, Administrasi dan Finansial Peradilan

e) Hak uji peraturan Toetsingsrecht

f) Forum Privilegiatum

g) Hukum Acara

h) Status dan Jaminan Hakim

i) Connexiteit

j) Lembaga Henzeining (Peninjauan Kembali)

Kecuali persoalan b) dan f) yaitu tentang Majelis Pertimbangan Penelitian Hakim (MPPH) dan Forum Privilegiatum semua persoalan-persoalan itu (ius constituendum) telah menjelma menjadi hukum positif (positifitus constitutum) diatur dalam berbagai pasal UU Nomor 14 Tahun 1970. Khusus tentang jenis-jenis kekuasaan kehakiman, UU Nomor 14 Tahun 1970, mengaturnya dalam Pasal 10 ayat (1). Menurut Pasal itu, kekuasaan kehakiman dilaksanakan oleh:

a) Peradilan Umum

b) Peradilan Agama

c) Peradilan Militer

d) Peradilan Tata Usaha Negara

Tentang Peradilan Umum lebih jauh diatur dengan UU Nomor 2 Tahun 1986 yang sekaligus mencabut UU Nomor 13 Tahun 1965 tentang Pengadilan Dalam Lingkungan Peradilan Umum dan Mahkamah Agung. Pasal 3 ayat (1) UU Nomor 2 Tahun 1986 menyatakan bahwa kekuasaan kehakiman di lingkungan Peradilan Umum dilaksanakan oleh Pengadilan Negeri dan Pengadilan Tinggi, masing-masing berkedudukan di Ibu Kota Kabupaten (Kotamadya) dan Ibu Kota Propinsi (Pasal 4). Pengadilan Negeri merupakan pengadilan Tingkat pertama dan Pengadilan Tinggi merupakan Pengadilan Tingkat Banding.

Perihal Peradilan Agama, keberadaannya lebih jauh diatur dengan Undang-undang Nomor 7 Tahun 1989. Sebagai Peradilan Khusus, Pasal 1 ayat (1) menegaskan Peradilan Agama adalah peradilan bagi orang-orang yang beragama Islam. Kekuasaan kehakiman pada Peradilan Agama dilaksanakan oleh Pengadilan Agama yang berkedudukan di Kotamadya atau ibu kota Kabupaten dan Pengadilan Tinggi Agama berkedudukan di Ibukota Propinsi. Sama halnya dengan Peradilan Umum, Kekuasaan kehakiman di lingkungan Peradilan Agama berpuncak pada Mahkamah Agung.

Berkenan dengan Peradilan Militer, lebih jauh peradilan ini diatur dengan Undang-undang Nomor 31 tahun 1997. Sebagai peradilan khusus. Pasal 9 UU tersebut menyatakan; Peradilan Militer berwenang mengadili pidana militer dan perkara pidana militer: a) 
prajurit; b) mereka yang berdasarkan Undang-undang dipersamakan dengan prajurit; c) anggota suatu golongan atau jawatan atau badan atau yang dipersamakan atau dianggap sebagai prajurit berdasarkan Undang-undang; d) seorang yang tidak masuk golongan pada huruf $\mathrm{a}$, huruf $\mathrm{b}$ dan huruf $\mathrm{c}$, tetapi atas keputusan Penglima dengan persetujuan Menteri Kehakiman harus diadili oleh suatu pengadilan dalam lingkungan Peradilan Militer. Selain kewenangan itu, Peradilan Militer berwenang menggabungkan perkara gugatan ganti rugi dalam perkara pidana atas permintaan pihak yang dirugikan dan sekaligus memutus dua perkara pidana dan perdata itu dalam satu putusan.

Adapun kekuasaan kehakiman dalam lingkungan Peradilan Militer dijalankan oleh:

a) Pengadilan Militer

b) Pengadilan Militer Tinggi

c) Pengadilan Militer Utama

d) Pengadilan Militer Pertempuran

Tempat kedudukan Pengadilan Militer Utama berada di Ibukota Negara RI, sementara Pengadilan Militer yang lainnya tempat kedudukannya lebih lanjut diatur dengan keputusan Panglima. Pengadilan Militer merupakan pengadilan tingkat pertama bagi prajurit yang berpangkat Kapten ke bawah. Pengadilan Militer Tinggi merupakan pengadilan banding bagi Pengadilan Militer dan merupakan pengadilan tingkat pertama bagi prajurit yang berpangkat Mayor ke atas. Pengadilan Militer utama merupakan Pengadilan banding dan merupakan pengadilan militer atas Pengadilan Militer Tinggi yang telah memutus pada tingkat pertama perkara pidana militer dan perakara tata usaha angkatan bersenjata. Sementara Pengadilan Militer Pertempuran adalah pengadilan yang agak spesifik karena pengadilan ini bersifat mobil mengikuti gerakan pasukan serta kedudukannya di daerah pertempuran. Pengadilan ini berwenang memutus perkara pidana militer pada tingkat pertama dan terakhir yang tertuduh atau terdakwanya prajurit yang terlibat kegiatan pertempuran.

Terakhir, mengenai Peradilan Tata Usaha Negara, keberadaan peradilan ini diatur dalam Undang-undang Nomor 5 Tahun 1986. Sifat khusus dari peradilan ini ditegaskan dalam Pasal 4 UU tersebut yang menyatakan bahwa Peradilan tata Usaha Negara adalah salah satu pelaksana kekuasan kehakiman bagi rakyat pencari keadilan terhadap sengketa Tata Usaha Negara. Pelaksana kekuasaan kehakiman dalam lingkungan Peradilan Tata Usaha Negara dilaksanakan oleh: a) Pengadilan Tata Usaha Negara yang berkedudukan di Kotamadya atau ibu kota Kabupaten; b) Pengadilan Tinggi Tata Usaha Negara yang berkedudukan di Ibukota Propinsi, Pengadilan Tata Usaha Negara berpuncak ke Mahkamah Agung.

Peradilan Tata Usaha Negara berwenang memeriksa, memutus dan menyelesaikan sengketa tata usaha negara. Jika suatu sengketa tata usaha negara tertentu menurut Undang-undang tertentu harus diselesaikan dengan upaya administratif, maka Pengadilan Tata Usaha Negara berwenang mengadili jika sebelumnya telah ditempuh upaya administratif tersebut. Pengadilan tidak berwenang mengadili sengketa Tata Usaha Negara dalam hal keputusan yang disengketakan itu dikeluarkan: a) dalam waktu perang, keadaan bahaya, keadaan bencana alam atau keadaan luar biasa yang membahayakan, berdasarkan peraturan perundang-undangan yang berlaku; b) dalam keadaan mendesak untuk kepentingan umum berdasarkan peraturan perundang-undangan yang berlaku.

\section{SIMPULAN}

Dilihat dari sejarahnya kekuasaan kehakiman telah mengalami perkembangan yang sangat panjang sesuai situasi dan kondisi politik yang terus berkembangan menurut era ketatanegaraan yang mengikutinya. Pada masa pemerintahan Hindia Belanda badan-badan peradilan yang dibentuk sebagai pelaksana kekuasaan kehakiman bersifat pluralistik dan diskriminatif dengan membedakan peradilan yang khusus untuk orang-orang eropa atau yang dipersamakan dengannya dan badan peradilan yang khusus untuk golongan pribumi dengan peradilan adatnya.

Peradilan Gubernemen bertugas mengadili atau melaksanakan fungsinya atas nama Raja atau Ratu Belanda, sedangkan Peradilan Adat menjalankan kekuasaan kehakiman berdasarkan hukum adat di daerah setempat. Dalam prakteknya peradilan adat ini bukanlah bentuk peradilan yang bebas dan merdeka karena Residen yang diangkat oleh pemerintah Hindia Belanda mempunyai kewenangan untuk membatalkan putusan pengadilan adat atau memerintahkan pemeriksaan kembali oleh hakim yang ditunjuk oleh Residen dan Residen berkuasa untuk menetapkan bahwa seseorang tidak termasuk ke dalam jurusdiksi Peradilan Adat setempat.

Pada masa pemerintahan militer Jepang sesuai karakteristik pemerintah penjajahan Jepang di Indonesia berupa pemerintah militer yang bertujuan untuk menjaga keselamatan dan keamanan personil militer Jepang, peradilan yang dibentuk oleh pemerintah militer Jepang adalah peradilan yang melindungi militer yang disebut Gunritukaigi. Selain peradilan yang bersifat melindungi kepentingan milter, dibentuklah Gunsei Hoin dan Gunsei Kensatu Kyoku.

Setelah Indonesia merdeka, kebijakan yang ditempuh berkaitan dengan pengembangan kekuasaan kehakiman adalah didasari pada prinsip "unifikasi", sebagai lawan dari prinsip "pluralistis" yang diterapkan pada masa pemerintah kolonial Belanda". "Unifikasi" itu kemudian muncul dalam kekuasaaan kehakiman yang bebas dan merdeka yang pada dasarnya terjelma dalam empat lingkungan peradilan yang terdiri dari: Peradilan Umum, Peradilan Militer, Peradilan Agama dan Peradilan Tata Usaha Negara dimana masing-masing lingkungan peradilan ini berpuncak pada Mahkamah 
Agung, sebagai lembaga tertinggi pemegang kekuasaan kehakiman yang bebas dan merdeka.

\section{DAFTAR PUSTAKA}

Bagir Manan, Kekuasaan Kehakiman Republik Indonesia, Universitas Islam Bandung, 1995.

Bob Brouwer (et.al), Cohorence and Conflict in Law, WEJ Tjeenk Willink, Zwolle, Netherland, 1992.

C.F. Strong OBE, Modern Political Constitution, Sidgewick \& Jackson Limited, London, 1952.

DCM Yordley, Introduction to British Constitusional Law, Butter Worths, London, 1969.

Fergus on \& Mc Henry, The American System of Government, Mc Graw-Hill Book Company, New York, Dst., 1965.

H. McCourbey \& ND White, Text Boook on Jurisprudence, Black Stone Press, Ltd., London, 1996.

JB. Grossman \& RS Well, Constitution Law and Judicial Policy Making, John Willey \& Sons, Toronto, New York, London, Sydney, 1972.

L Lloyd of Hampsted \& MDA Freeman, Lloyd's Introduction to Jurispuredence, Stevens \& Sons, London, 1985.

Philipus M. Hadjon, Lembaga Tertinggi dan LembagaLembaga Tinggi Negara Menurut UUD 1945, Suatu Analisa Hukum dan Kenegaraan, PT. Bina Ilmu, Surabaya, 1987.

Soedirdjo, Mahkamah Agung, Kedudukan, Susunan dan Kekuasaannya, Media Sarana Press, Jakarta, 1987.

W. Friedman, The State and The Rule of Law In Mixed Economy, Steven \& Sons, London, 1971.

W. Keefe \& M.S. Ogul, The American Legislative Process, Prentice Hall, Inc, Engle Cliffs, New Jersey, 1964.

Wirijono Prodjodikoro, Hukum Negara dan Politik, Universitas Katolik Parahyangan, Bandung, 1971. 